\title{
Mapping $\mathrm{P} 2 \mathrm{X}$ and $\mathrm{P} 2 \mathrm{Y}$ receptor proteins in striatum and substantia nigra: An immunohistological study
}

\author{
Susanna Amadio • Cinzia Montilli • Barbara Picconi • \\ Paolo Calabresi • Cinzia Volonté
}

Received: 3 July 2007 / Accepted: 31 July 2007 / Published online: 5 September 2007

(C) Springer Science + Business Media B.V. 2007

\begin{abstract}
Our work aimed to provide a topographical

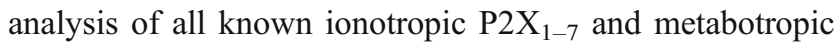
$\mathrm{P} 2 \mathrm{Y}_{1,2,4,6,11-14}$ receptors that are present in vivo at the protein level in the basal ganglia nuclei and particularly in rat brain slices from striatum and substantia nigra. By immunohistochemistry-confocal and Western blotting techniques, we show that, with the exception of $\mathrm{P} 2 \mathrm{Y}_{11,13}$ receptors, all other subtypes are specifically expressed in these areas in different amounts, with ratings of low $\left(\mathrm{P}^{2} \mathrm{X}_{5,6}\right.$ and $\mathrm{P} 2 \mathrm{Y}_{1,6,14}$ in striatum), medium ( $\mathrm{P}_{2} \mathrm{X}_{3}$ in striatum and substantia nigra, $\mathrm{P} 2 \mathrm{X}_{6,7}$ and $\mathrm{P} 2 \mathrm{Y}_{1}$ in substantia nigra) and high. Moreover, we describe that $\mathrm{P} 2$ receptors are localized on neurons (colocalizing with neurofilament light, medium and heavy chains) with features that are either dopaminergic (colocalizing with tyrosine hydroxylase) or GABAergic (colocalizing with parvalbumin and calbindin), and they are
\end{abstract}

S. Amadio · C. Montilli • B. Picconi · P. Calabresi · C. Volonté

Santa Lucia Foundation,

Rome, Italy

P. Calabresi

Clinica Neurologica, Università di Perugia,

Ospedale S. Maria della Misericordia,

Perugia, Italy

C. Volonté

C.N.R. Institute of Neurobiology and Molecular Medicine,

Rome, Italy

S. Amadio $(\bowtie)$

Santa Lucia Foundation/Institute of Neurobiology and Molecular

Medicine, CNR,

Via del Fosso di Fiorano 65,

00143 Rome, Italy

e-mail: s.amadio@hsantalucia.it also present on astrocytes ( $\mathrm{P}_{2} \mathrm{Y}_{2,4}$, colocalizing with glial fibrillary acidic protein). In addition, we aimed to investigate the expression of $\mathrm{P} 2$ receptors after dopamine denervation, obtained by using unilateral injection of 6hydroxydopamine as an animal model of Parkinson's disease. This generates a rearrangement of $\mathrm{P} 2$ proteins: most P2X and P2Y receptors are decreased on GABAergic and dopaminergic neurons, in the lesioned striatum and substantia nigra, respectively, as a consequence of dopaminergic denervation and/or neuronal degeneration. Conversely, $\mathrm{P} 2 \mathrm{X}_{1,3,4,6}$ on GABAergic neurons and $\mathrm{P}_{2} \mathrm{Y}_{4}$ on astrocytes augment their expression exclusively in the lesioned substantia nigra reticulata, probably as a compensatory reaction to dopamine shortage. These results disclose the presence of P2 receptors in the normal and lesioned nigro-striatal circuit, and suggest their potential participation in the mechanisms of Parkinson's disease.

Keywords Parkinson's disease $\cdot$ Purinergic receptors .

Rat brain - Tyrosine hydroxylase $\cdot \gamma$-Aminobutyric acid . 6-Hydroxydopamine

$\begin{array}{ll}\text { Abbreviations } \\ \text { BG } & \text { Basal ganglia } \\ \text { GABA } & \gamma \text {-Aminobutyric acid } \\ \text { GFAP } & \text { Glial fibrillary acidic protein } \\ \text { NF-L } & \text { Neurofilament-L protein } \\ \text { 6-OHDA } & \text { 6-Hydroxydopamine } \\ \text { MBP } & \text { Myelin basic protein } \\ \text { P2r } & \text { P2 receptors } \\ \text { SN } & \text { Substantia nigra } \\ \text { SNC } & \text { Substantia nigra pars compacta } \\ \text { SNR } & \text { Substantia nigra pars reticulata } \\ \text { TH } & \text { Tyrosine hydroxylase }\end{array}$




\section{Introduction}

It is now well established that the arrangement of ionotropic $\mathrm{P} 2 \mathrm{X}$ and metabotropic $\mathrm{P} 2 \mathrm{Y}$ receptors $[1,2]$ on a cell membrane is a very dynamic process, often related to developmental or physiopathological conditions. Moreover, it is common knowledge that multiple P2 proteins are simultaneously recruited on a cell membrane for triggering biological functions. As a consequence, P2 receptors are rightly considered more than the sum of their single entities and must be therefore regarded as a complex network of cooperating receptors. Under this perspective, a numerical model was also introduced, the combinatorial receptor web model, which explains the biological efficacy of combining an assorted array of different P2 proteins on a given cell, in order to integrate, upgrade, guarantee and optimize specific receptor-dependent functions [3].

This trend of course applies to the central nervous system (CNS) as well, where in situ hybridization of P2 mRNA subtypes and immunohistochemistry of P2 proteins shows, for instance, wide but heterogeneous simultaneous distribution of both P2X [4-11] and P2Y [12-15] classes of receptors. In particular, $\mathrm{P} 2 \mathrm{X}_{2,4,6}$ and $\mathrm{P} 2 \mathrm{Y}_{1}$ subtypes are abundant and widespread approximately in the entire brain, while $\mathrm{P} 2 \mathrm{X}_{1}$ protein is enriched in the cerebellum, $\mathrm{P} 2 \mathrm{X}_{3}$ in the brain stem, and $\mathrm{P} 2 \mathrm{X}_{7}$ is largely prejunctional. The hippocampus concurrently expresses all $\mathrm{P} 2 \mathrm{X}$ and, moreover, $\mathrm{P} 2 \mathrm{Y}_{1,2,4,6,12}$ receptor subtypes. Particularly in the basal ganglia (BG), neostriatal medium-spiny neurons and cholinergic interneurons highly express $\mathrm{P}_{2} \mathrm{X}_{2}$ and $\mathrm{P} 2 \mathrm{Y}_{1}$ receptors, but it appears that they become functional only under certain, as yet unknown, conditions [16]. Moreover, $\mathrm{P}_{2} \mathrm{X}_{2}$ receptor protein was described in substantia nigra pars compacta (SNC) [17], whereas both protein and mRNA were described in SNC and striatum [18]. Finally, only very low levels of $\mathrm{P} 2 \mathrm{X}_{4,6}$ mRNAs were detected in substantia nigra (SN) and striatum [19].

By functional analysis, ATP release was demonstrated from cultured embryonic neostriatal neurons [20], and ATPevoked potassium currents in rat striatal neurons were shown to be mediated by $\mathrm{P} 2$ receptors [21]. ATP was also proved to increase extracellular dopamine levels in rat striatum through stimulation of P2Y subtypes [22], although it was claimed to inhibit dopamine release in the neostriatum [23]. Extracellular ATP via P2 receptors was finally reported to induce neurotoxicity in vitro [24] and in vivo [25] in the striatum. Besides $\mathrm{P} 2$ receptors on neurons, in $\mathrm{BG}$ there is also evidence of $\mathrm{P} 2$ receptors on, and release of ATP from, glial cells. P2 $\mathrm{Y}_{12}$ subtype is present, for instance, on oligodendrocytes in striatum and SN [26], and $\mathrm{P}_{2} \mathrm{X}_{7}$ receptor is upregulated on microglia in striatum after middle cerebral artery occlusion [27]. In spite of these results, there is a general paucity of studies addressing the cellular distribution of all $\mathrm{P} 2$ receptor proteins in $\mathrm{BG}$.
Our work thus aimed to provide the complete topographical analysis of known P2X and P2Y subtypes that are present in rat striatum and $\mathrm{SN}$ in vivo, and to investigate the dynamic presence of $\mathrm{P} 2$ proteins after the induction of experimental parkinsonism by dopamine-denervation achieved by using the unilateral 6-hydroxydopamine (6OHDA) rat model. By upgrading the current map of P2 receptors expressed in the brain, our study discloses the potential impact of these receptors in the normal and lesioned nigro-striatal circuit.

\section{Materials and methods}

\section{Histological procedures}

Wistar rats (Harlan, Udine, Italy) were anesthetized by i.p. injections of sodium pentobarbital $(60 \mathrm{mg} / \mathrm{kg})$, and transcardially perfused with saline $(0.9 \% \mathrm{NaCl})$ followed by $4 \%$ paraformaldehyde, in phosphate buffer (PB, 0.1 M pH 7.4). Each brain was immediately removed, post-fixed in the same fixative for $2 \mathrm{~h}$, and then transferred to $30 \%$ sucrose in $\mathrm{PB}$ at $4^{\circ} \mathrm{C}$, until it sank. The experimental protocol used in this study was approved by the Italian Ministry of Health and was in agreement with the guidelines of the European Communities Council Directive of November 24, 1986 (86/ $609 / \mathrm{EEC}$ ) for the care and use of laboratory animals. All efforts were made to minimize the number of animals used and their suffering.

\section{Double immunofluorescence}

Transverse sections (40- $\mu \mathrm{m}$ thick) were cut on a freezing microtome and were processed for double immunofluorescence studies. Non-specific binding sites were blocked with $10 \%$ normal donkey serum in $0.3 \%$ Triton $\mathrm{X}-100$, in phosphate buffered saline (PBS) for $30 \mathrm{~min}$ at room temperature. The sections were incubated in a mixture of primary antisera for $24-48 \mathrm{~h}$ in $0.3 \%$ Triton X-100 in PBS. Rabbit anti-P2r (1:300, Alomone, Jerusalem, Israel) was used in combination with either mouse anti-calbindin-D-28K (1:200, Sigma, Mi, Italy), mouse anti-tyrosine hydroxylase (TH, 1:500, Sigma), mouse anti-parvalbumin (1:200, Chemicon International, Temecula, CA, USA), mouse anti-glial fibrillary acidic protein (GFAP) (1:400, Sigma), mouse antimyelin basic protein (MBP, 1:200, Chemicon International), mouse anti-neurofilament $\mathrm{H}$ non-phosphorylated (SMI 32, 1:500, Sternberger Monoclonals, Lutherville, MD, USA), mouse anti-neurofilament $\mathrm{H}$ and $\mathrm{M}$ non-phosphorylated (SMI 33, 1:500, Sternberger Monoclonals), mouse antineurofilament 160 (NF160, 1:500, Sigma) or goat antineurofilament-L protein (NF-L, 1:100, Santa Cruz, Mi, Italy). The secondary antibodies used for double labeling 
were Cy3-conjugated donkey anti-rabbit $\operatorname{IgG}(1: 100$, red immunofluorescence, Jackson Immunoresearch, West Baltimore Pike, PA, USA), Cy2-conjugated donkey anti-mouse IgG (1:100, green immunofluorescence, Jackson Immunoresearch) or Cy2-conjugated donkey anti-goat IgG (1:100, green immunofluorescence, Jackson Immunoresearch).

The sections were washed in PBS three times for $5 \mathrm{~min}$ each, and then incubated for $3 \mathrm{~h}$ in a solution containing a mixture of the secondary antibodies in $1 \%$ normal donkey serum in PBS. After rinsing, the sections were mounted on slide glasses, allowed to air dry and coverslipped with gel/ mount anti-fading medium (Biomeda, Foster City, CA, USA).

\section{Confocal microscopy}

Double- or triple-label immunofluorescence was analyzed by means of a confocal laser scanning microscope (CLSM) (LSM 510, Zeiss, Arese, Mi, Italy) equipped with argon laser emitting at $488 \mathrm{~nm}$, helium/neon laser emitting at $543 \mathrm{~nm}$, and helium/neon laser emitting at $633 \mathrm{~nm}$. Specificity of the antibodies was positively proved by performing confocal analysis in the absence of the primary antibodies, but in the presence of either anti-rabbit or antimouse secondary antibodies. Specificity was further confirmed for the $\mathrm{P} 2 \mathrm{r}$ antiserum by performing immunoreactions in the simultaneous presence of the P2r neutralizing immunogenic peptides.

\section{Isolation of cerebral areas and protein extraction}

Wistar rats were anesthetized by i.p. injections of sodium pentobarbital $(60 \mathrm{mg} / \mathrm{kg})$ and, after decapitation, brains were removed. Each brain was transversally cut on a vibratome $(300 \mu \mathrm{m})$. The specific cerebral areas were isolated with the aid of a dissection microscope and homogenized in RIPA buffer (1\% Nonidet P-40, 0.5\% sodium deoxycholate, $0.1 \% \mathrm{SDS}$ in PBS containing protease inhibitors). After short sonication, the homogenates were incubated on ice for $1 \mathrm{~h}$ and centrifuged at 14,000 r.p.m. for $10 \mathrm{~min}$ at $4^{\circ} \mathrm{C}$. Protein quantification was performed in the supernatants by Bradford colorimetric assay (Biorad, Milan, Italy).

Western blot analysis

Equal amounts of cell lysate $(20-30 \mu \mathrm{g}$ of protein from each cerebral area) were separated by electrophoresis on 10-12\% SDS-PAGE and transferred to nitrocellulose membranes Hybond-C extra (Amersham Biosciences, Cologno Monzese, Italy). The filters were pre-wetted in $5 \%$ non-fat milk in TBS-T $(10 \mathrm{mM}$ Tris $\mathrm{pH} 8,150 \mathrm{mM}$ $\mathrm{NaCl}, 0.1 \%$ Tween 20) and hybridized overnight with $\mathrm{P} 2 \mathrm{X}_{1,2,4}$ antisera (Alomone, 1:500), $\mathrm{P} 2 \mathrm{X}_{5}$ and $\mathrm{P} 2 \mathrm{Y}_{4 / 14}$
(1:200), $\mathrm{P}_{2} \mathrm{Y}_{6}(1: 300)$ or $\mathrm{P} 2 \mathrm{Y}_{2}(1: 400)$. The antisera were immunodetected with an anti-rabbit HRP-conjugated antibody $(1: 5,000)$ and developed by ECL chemiluminescence (Amersham Biosciences), using Kodak Image Station (KDS IS440CF).

\section{Anti-P2r specificity}

The polyclonal $\mathrm{P} 2 \mathrm{r}$ antisera used in this study were raised against P2r highly purified peptides (identity confirmed by mass spectrography and amino acid analysis, as indicated in the certificate of analysis provided by the manufacturer), corresponding to specific epitopes not present in any other known protein. The specificity of the $\mathrm{P} 2 \mathrm{r}$ signals was moreover assessed by incubating Western blots either in the absence of the primary antiserum, or in the presence of the primary antiserum together with the neutralizing $\mathrm{P} 2 \mathrm{r}$ immunogenic peptides ( $\mu \mathrm{g}$ protein ratio $1: 1$ between peptide and antiserum).

\section{6-OHDA lesion and Nissl staining}

Deeply anesthetized rats (45 days old, about $150 \mathrm{~g}$ body weight) were injected with $8 \mu \mathrm{g} / 4 \mu \mathrm{l}$ 6-OHDA in saline $0.1 \%$ ascorbic acid in the medial forebrain bundle (stereotaxic coordinates ap $=-4.4 ; 1=+1.2 ; \mathrm{vd}=-7.8$, see also Paxinos et al. [28]) at a rate of $0.38 \mu \mathrm{l} / \mathrm{min}$. Fifteen days later, the lesioned rats were tested with $0.05 \mathrm{mg} / \mathrm{kg}$ s.c. of the D1/D2 dopamine agonist apomorphine, in order to verify the efficacy of the 6-OHDA lesion, and contralateral turns to the lesion were counted for $40 \mathrm{~min}$. Only those rats that made at least 200 contralateral turns were used for the study. It has been previously demonstrated that rats meeting this screening criterion have greater than 95\% depletion of striatal dopamine [29]. At 1.5 months after the 6-OHDA lesion, rats were used for immunohistological experiments $(n=3)$. In order to evaluate cell damage, $40-\mu \mathrm{m}$ rat brain sections were mounted onto gelatinized slides. They were dehydrated through alcohols, and then rehydrated and stained in $2 \%$ cresyl violet for $45 \mathrm{~min}$. Following deionized water rinses, the slides were dehydrated in a standard alcohol series, cleared in xylene, and coverslipped.

\section{Results}

$\mathrm{P} 2 \mathrm{X}$ and $\mathrm{P} 2 \mathrm{Y}$ receptor proteins in rat striatum

We describe in this work the cellular and subcellular in vivo distribution of $\mathrm{P} 2 \mathrm{X}$ and $\mathrm{P} 2 \mathrm{Y}$ receptors in transverse sections of adult rat striatum, showing by double immunofluorescence confocal analysis that the various P2 subtype proteins are distinguished by different degrees of expres- 

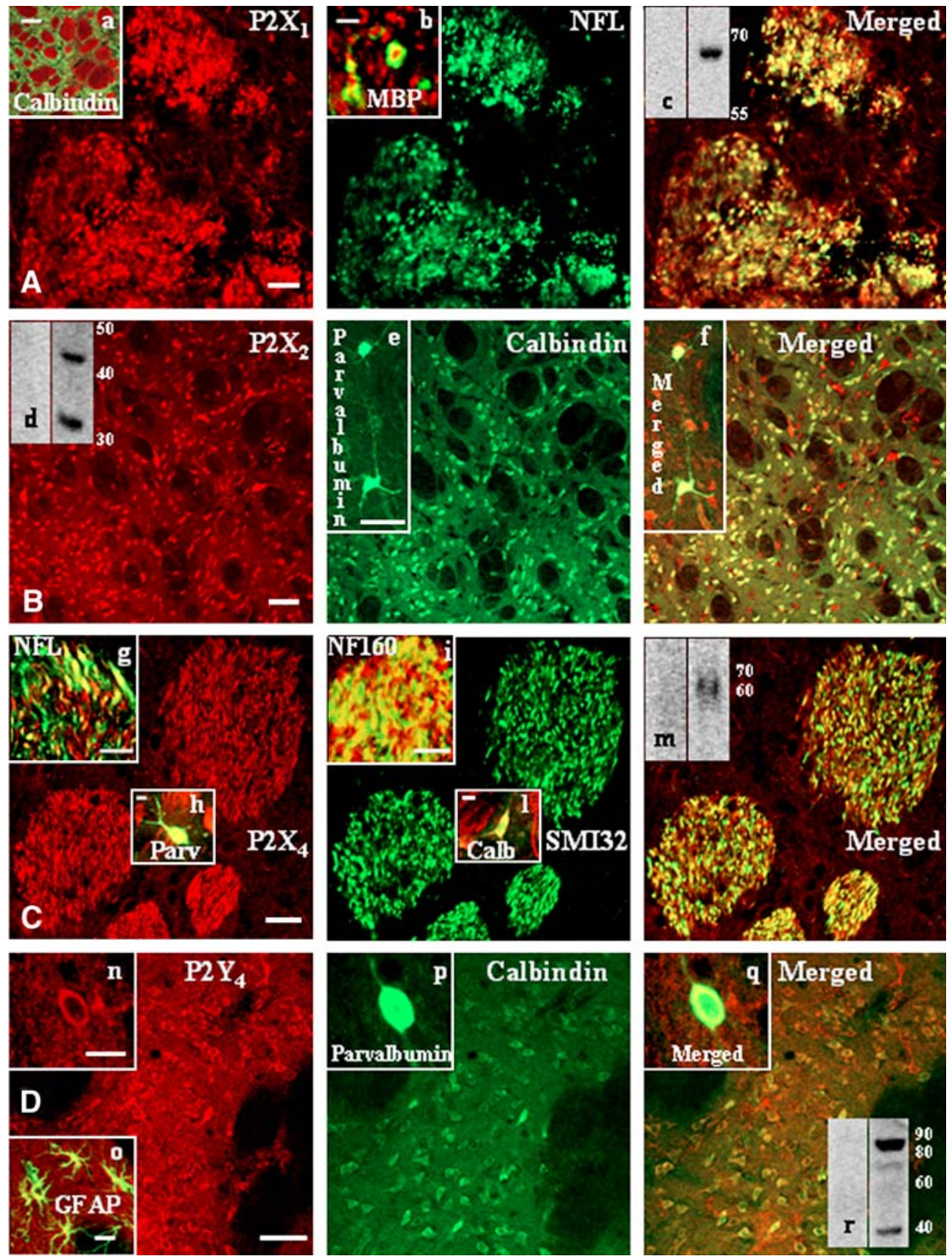

Fig. $1 \mathrm{P} 2 \mathrm{X}$ and $\mathrm{P} 2 \mathrm{Y}$ receptor proteins in rat striatum. Transverse sections through the striatum of adult rats were processed for double immunofluorescence studies. Rabbit polyclonal antisera against $\mathrm{P} 2 \mathrm{X}_{1,2,4}$ and $\mathrm{P}_{2} \mathrm{Y}_{4}$ receptors (red $\mathrm{Cy} 3$ immunofluorescence) were used in combination with antibodies against neuronal or glial markers (green Cy2 immunofluorescence). Panel $A \mathrm{P}_{2} \mathrm{X}_{1}$ : confocal images illustrate clear colocalization of $\mathrm{P} 2 \mathrm{X}_{1}$ receptor with neurofilament-light protein (NF-L). The merged field of inset $a$ shows absence of colocalization between the neuronal GABAergic marker calbindin (green) (a calciumbinding protein expressed mainly in medium spiny neurons of the striatum) and $\mathrm{P} 2 \mathrm{X}_{1}$ receptor (red). The merged field of inset $b$ shows the merged field of $\mathrm{P}_{2} \mathrm{X}_{1}$ (red) and MBP (green) overlapping immunoreactivities at higher magnification. Panel $B \mathrm{P} 2 \mathrm{X}_{2}$ : double immunofluorescence demonstrates that $\mathrm{P} 2 \mathrm{X}_{2}$ receptor immunoreactivity (red) colocalizes with calbindin protein (green). The insets $e$ and $f$ show colocalization with the neuronal GABAergic marker parvalbumin (green) (a calcium-binding protein that is expressed in interneurons of the striatum). Panel $C \mathrm{P} 2 \mathrm{X}_{4}$ : red immunofluorescence for $\mathrm{P} 2 \mathrm{X}_{4}$ protein merges with the green signals of the three types of neurofilament proteins: NF-L (inset $g$, merged field), NF160 (inset $i$, merged field) and SMI 32 and, moreover, with parvalbumin (inset $h$, merged field) and calbindin (inset $i$, merged field). Panel $D \mathrm{P}_{2} \mathrm{Y}_{4}$ : red $\mathrm{P}_{2} \mathrm{Y}_{4}$ immunoreactivity is present on calbindin-positive neurons (green), on parvalbumin-positive neurons (green) (insets $n-q$ ), and on GFAP-positive astrocytes (inset $o$, merged field). Western blot analysis also confirms the presence of receptor proteins $\mathrm{P} 2 \mathrm{X}_{1,2,4}$ (insets $c$ in panel $A, d$ in panel $B, m$ in panel $C$, respectively) and $\mathrm{P}_{2} \mathrm{Y}_{4}$ (inset $r$ in panel $D$ ) in striatum. Specificity of the $\mathrm{P} 2$ receptor signals was assessed by incubations of the primary antisera with the corresponding neutralizing immunogenic peptides ( $\mu \mathrm{g}$ protein ratio 1:1 between peptide and antiserum). Scale bars are $10 \mu \mathrm{m}$ in $A ; 100 \mu \mathrm{m}$ in inset $a ; 2 \mu \mathrm{m}$ in inset $b ; 50 \mu \mathrm{m}$ in $B$ and in insets $e$ and $f ; 20 \mu \mathrm{m}$ in $C ; 10 \mu \mathrm{m}$ in insets $h, i, l ; 5 \mu \mathrm{m}$ in inset $g$; $50 \mu \mathrm{m}$ in $D ; 5 \mu \mathrm{m}$ in inset $n$; and $20 \mu \mathrm{m}$ in inset $o$. Similar results were obtained in at least four independent experiments 
sion and are not uniformly distributed throughout the entire tissue (Fig. 1).

In particular, a strong $\mathrm{P} 2 \mathrm{X}_{1}$ receptor immunoreactivity (red) confers a patchy appearance to the striatum, being localized mainly in white matter, while sparing the projecting calbindin-positive GABAergic neurons that are highly enriched in gray matter (Fig. $1 A$, inset $a$, green). Moreover, $\mathrm{P} 2 \mathrm{X}_{1}$ protein immunofluorescence is present on NF-L positive, transversally oriented neuronal fibers, although the merged field provides only partial colocalization between the two signals (Fig. 1A). In addition, the high magnification analysis (Fig. $1 A$, inset $b$ ) of $\mathrm{P}_{2} \mathrm{X}_{1}$ (red) and MBP (green) immunoreactive signals shows that $\mathrm{P}_{2} \mathrm{X}_{1}$ receptor is surrounded by MBP, proving the presence of $\mathrm{P} 2 \mathrm{X}_{1}$ protein on myelinated fibers. Due to the close vicinity of the two signals, overlapping yellow immunofluorescence is also observed. Finally, $\mathrm{P}_{2} \mathrm{X}_{1}$ receptor in striatum is recognized by Western blot analysis as a single protein band of $60-65 \mathrm{kDa}$, additionally abolished in the presence of the $\mathrm{P} 2 \mathrm{X}_{1}$ receptor-neutralizing immunogenic peptide (Fig. 1A, inset $c$ ).

Conversely, an abundant $\mathrm{P} 2 \mathrm{X}_{2}$ receptor immunoreactivity (red) is found in gray matter of striatum (Fig. 1B), while sparing the bundles of white matter. Specific receptor immunolabeling is present not only on the highly expressed calbindin-positive projecting GABAergic neurons, but also on the fewer parvalbumin-positive GABAergic interneurons (Fig. $1 B$, insets $e, f$ ). By Western blot analysis, we show that $\mathrm{P} 2 \mathrm{X}_{2}$ receptor is present in striatum under two isoforms of about 45 and $32 \mathrm{kDa}$, furthermore, it is abolished in the presence of the $\mathrm{P} 2 \mathrm{X}_{2}$ receptor-neutralizing immunogenic peptide (Fig. $1 B$, inset $d$ ).

$\mathrm{P} 2 \mathrm{X}_{3}$ receptor immunostaining in striatum is of medium intensity (Table 1), and mainly localizes on GABAergic neurons of gray matter (data not shown).

$\mathrm{P} 2 \mathrm{X}_{4}$ receptor signal is instead very copious in white matter, although present on a few fibers of gray matter as well (Fig. $1 C$, red). It partially colocalizes with all types of heavy-, light- and medium-chain neurofilament proteins (merged fields): SMI 32 (green), NF-L (inset $g$ ), and NF160 (inset $i$ ). Moreover, we find $\mathrm{P}_{2} \mathrm{X}_{4}$ protein also on GABAergic interneurons (inset $h$ ) and GABAergic spiny neurons (inset $l$ ). By Western blot analysis, we demonstrate that $\mathrm{P} 2 \mathrm{X}_{4}$ receptor is present in striatum as a single band of about $60 \mathrm{kDa}$, moreover, it is abolished in the presence of the $\mathrm{P}_{2} \mathrm{X}_{4}$ receptor-neutralizing immunogenic peptide (Fig. $1 C$, inset $m$ ).

$\mathrm{P} 2 \mathrm{X}_{5,6,7}$ and $\mathrm{P}_{2} \mathrm{Y}_{1}$ receptor immunoreactivities in striatum are very weak (Table 1 ) in gray matter, although totally absent from white matter under our experimental conditions (data not shown).

The $\mathrm{P}_{2} \mathrm{Y}_{2}$ receptor is highly expressed in striatum on axons of white matter and astrocytes of gray matter
(Table 1). Moreover, it is detected as a double protein band in the 55-65 $\mathrm{kDa}$ range (data not shown).

A strong $\mathrm{P}_{2} \mathrm{Y}_{4}$ receptor immunoreactivity is present only in gray matter of striatum, localized on both types of GABAergic neurons: calbindin-positive (Fig. 1D) and parvalbumin-positive (insets $n-q$ ). Nevertheless, the receptors are also widespread throughout the striatum on astrocytes, as shown by colocalization with the GFAP marker (inset $o$ ). By Western blot analysis, we prove that $\mathrm{P}_{2} \mathrm{Y}_{4}$ receptor is present in striatum as a double band of about 42 and $85 \mathrm{kDa}$ (inset $r$ ), likely corresponding to the monomeric and dimeric aggregation states of the receptor $[30,31]$.

While $\mathrm{P}_{2} \mathrm{Y}_{6}$ receptor is barely detectable (Table 1) on GABAergic neurons in striatum (data not shown), $\mathrm{P}_{2} \mathrm{Y}_{11,13,14}$ receptor proteins were not identified by any means under our experimental conditions (Table 1). Finally, $\mathrm{P}_{2} \mathrm{Y}_{12}$ receptor in striatum (Table 1) is abundantly expressed only on oligodendrocytes and myelin sheets, as previously shown [26].

\section{$\mathrm{P} 2 \mathrm{X}$ and $\mathrm{P} 2 \mathrm{Y}$ receptor proteins in substantia nigra}

We conducted a parallel analysis on the cellular and subcellular in vivo distribution of $\mathrm{P} 2 \mathrm{X}$ and $\mathrm{P} 2 \mathrm{Y}$ receptors in transverse sections of adult rat $\mathrm{SN}$. We showed by double immunofluorescence confocal analysis that the different P2 receptor proteins possess more comparable levels of expression with respect to the striatum, and are

Table 1 Map of P2 receptor proteins in striatum and substantia nigra

\begin{tabular}{|c|c|c|}
\hline & Striatum & Substantia nigra \\
\hline $\mathrm{P}_{2} \mathrm{X}_{1}$ & +++ & +++ \\
\hline $\mathrm{P} 2 \mathrm{X}_{2}$ & +++ & +++ \\
\hline $\mathrm{P} 2 \mathrm{X}_{3}$ & ++ & ++ \\
\hline $\mathrm{P} 2 \mathrm{X}_{4}$ & +++ & +++ \\
\hline $\mathrm{P}_{2} \mathrm{X}_{5}$ & + & +++ \\
\hline $\mathrm{P} 2 \mathrm{X}_{6}$ & + & ++ \\
\hline $\mathrm{P} 2 \mathrm{X}_{7}$ & ++ & ++ \\
\hline $\mathrm{P} 2 \mathrm{X}_{1}$ & + & ++ \\
\hline $\mathrm{P} 2 \mathrm{X}_{2}$ & +++ & +++ \\
\hline $\mathrm{P} 2 \mathrm{X}_{4}$ & +++ & +++ \\
\hline $\mathrm{P} 2 \mathrm{X}_{6}$ & + & +++ \\
\hline $\mathrm{P} 2 \mathrm{X}_{11}$ & - & - \\
\hline $\mathrm{P} 2 \mathrm{X}_{12}$ & +++ & +++ \\
\hline $\mathrm{P} 2 \mathrm{X}_{13}$ & - & - \\
\hline $\mathrm{P} 2 \mathrm{X}_{14}$ & - & +++ \\
\hline
\end{tabular}

Relative abundance of all $\mathrm{P} 2 \mathrm{X}$ and $\mathrm{P} 2 \mathrm{Y}$ receptor proteins was analyzed by confocal immunofluorescence microscopy, as described in "Materials and methods". The intensity of the specific immunostaining was scored as follow: $-=$ not detected; $+=$ just sufficient to evaluate presence and outline of positive cells; $++=$ adequate to assess morphological features of cell bodies and/or cellular processes; $+++=$ very bright 
also more uniformly, although differently, distributed throughout the entire SNC and SNR (Fig. 2). In particular, strong signals for ionotropic $\mathrm{P}_{2} \mathrm{X}_{2,5}$ (red, Fig. $2 A, B$ ), $\mathrm{P} 2 \mathrm{X}_{1,4}$ (Table 1), metabotropic $\mathrm{P} 2 \mathrm{Y}_{6,14}$ (red, Fig. $2 C, D$ ) and $\mathrm{P} 2 \mathrm{Y}_{4}$ (Table 1), or moderate signals for $\mathrm{P} 2 \mathrm{X}_{3,6}$ and $\mathrm{P} 2 \mathrm{Y}_{1}$ receptors (Table 1) are present on dopaminergic neurons (TH-positive) of SNC. Moreover, $\mathrm{P} 2 \mathrm{Y}_{2}$ and $\mathrm{P} 2 \mathrm{Y}_{12}$ receptors are abundantly expressed in SN (Table 1), but $\mathrm{P}_{2} \mathrm{Y}_{2}$ is expressed on axons and astrocytes, and $\mathrm{P}_{2} \mathrm{Y}_{12}$ only on oligodendrocytes and myelin sheets [26]. Conversely, in $\mathrm{SNR}$, a weak $\mathrm{P} 2 \mathrm{X} / \mathrm{Y}$ receptor immunoreactivity is limited to sparse neuronal bodies, likely identified as GABAergic neurons by colocalization with parvalbumin (data not shown). The presence at the tissue level in SN of ionotropic P2X $\mathrm{X}_{2,5}$ (insets $a$ in panel $A$, and $b$ in panel $B$ of Fig. 2, respectively) and metabotropic $\mathrm{P}_{2} \mathrm{Y}_{6,14}$ (insets $c$ in panel $C$, and $d$ in panel $D$ of Fig. 2, respectively) proteins is confirmed by Western blot analysis performed in all cases in the presence of specific receptor-neutralizing immunogenic peptides. Similarly to the striatum, immunoreactive signals for $\mathrm{P} 2 \mathrm{Y}_{11,13}$ receptors were not identified by any means under our experimental conditions (Table 1).
Fig. $2 \mathrm{P} 2 \mathrm{X}$ and $\mathrm{P} 2 \mathrm{Y}$ receptor proteins in rat substantia nigra. Double immunofluorescence visualized by confocal analysis was performed in transverse sections through the substantia nigra of adult rats. Strong signals for ionotropic $\mathrm{P} 2 \mathrm{X}_{2,5}$ and metabotropic $\mathrm{P}_{2} \mathrm{Y}_{6,14}$ (red Cy3 immunofluorescence) are present on dopaminergic neurons (TH-positive, green Cy2 immunofluorescence) of substantia nigra pars compacta (SNC), whereas in substantia nigra pars reticolata (SNR) P2X $\mathrm{Y}$ immunoreactivity is limited to sparse neuronal bodies. Western blot analysis confirms the presence in substantia nigra of receptor proteins $\mathrm{P} 2 \mathrm{X}_{2,5}$ (insets $a$ in panel $A$, and $b$ in panel $B$, respectively) and $\mathrm{P} 2 \mathrm{Y}_{6,14}$ (insets $c$ in panel $C$, and $d$ in panel $D$, respectively). Specificity of the $\mathrm{P} 2$ receptor signals was assessed by incubation of the primary antisera with the corresponding neutralizing immunogenic peptides ( $\mu$ g protein ratio 1:1 between peptide and antiserum) Scale bars in all panels are $50 \mu \mathrm{m}$. Similar results were obtained in at least four independent experiments
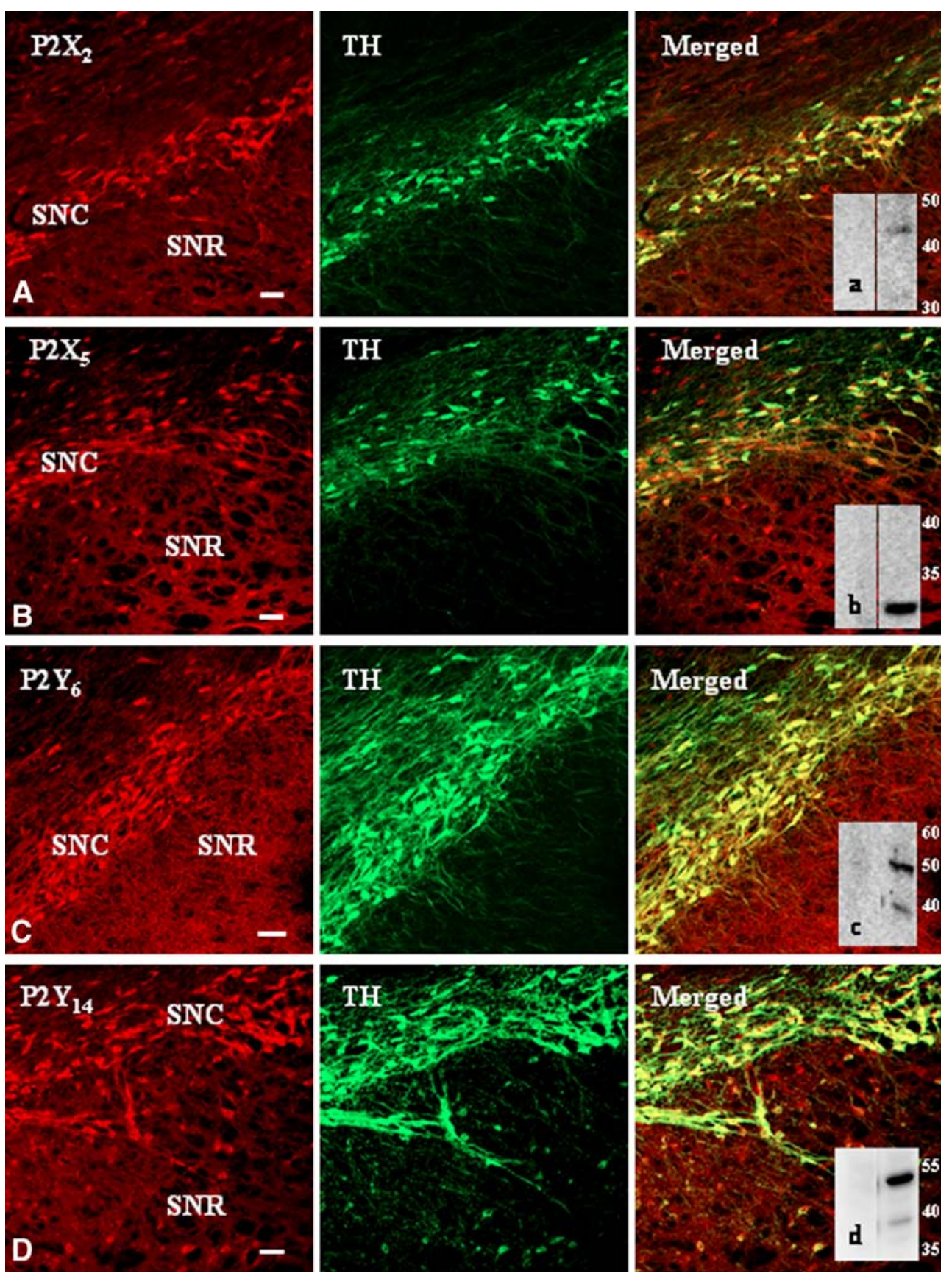
6-Hydroxydopamine modulates the expression of selected $\mathrm{P} 2$ receptors in striatum and substantia nigra

No contralateral rotation as a sign of motor deficit was reported in rats before being 6-OHDA-lesioned, but was instead detected after the lesion rotation (data not shown), together with loss of dopaminergic TH-positive neurons only from the ipsilateral hemisphere of SNC (Fig. $3 A$ and insets $a, b)$.

Concomitantly, we prove that dopamine denervation in the 6-OHDA-lesioned rat generates a significant and selective rearrangement of $\mathrm{P} 2$ receptor proteins. Whereas the expression pattern and immunofluorescence intensities of $\mathrm{P} 2 \mathrm{X}_{1,4}, \mathrm{P} 2 \mathrm{Y}_{2}$ (colocalizing with all neurofilaments and present in white matter on fibers projecting from the cortex), and $\mathrm{P}_{2} \mathrm{Y}_{12}$ (present on oligodendrocytes of white matter) remain constant in both ipsi- and contralateral hemispheres after 6-OHDA treatment (as well as in control animals), all other $\mathrm{P} 2 \mathrm{X}$ and $\mathrm{P} 2 \mathrm{Y}$ receptors are decreased on parvalbumin- and calbindin-positive GABAergic neurons of deafferented ipsilateral striatum (but not contralateral and in control animals), as measured by semiquantitative analysis (Table 2) $(n=3)$.

Similarly, all $\mathrm{P} 2 \mathrm{X}$ and $\mathrm{P} 2 \mathrm{Y}$ receptors are lost in the lesioned (but not contralateral) substantia nigra pars compacta, consequent to the degeneration of the majority of TH-positive dopaminergic neurons (Table 2). Conversely, $\mathrm{P} 2 \mathrm{X}_{1}$ (Fig. $3 B$ ) and $\mathrm{P} 2 \mathrm{X}_{3,4,6}$ (Table 2) receptors present on GABAergic neurons, and $\mathrm{P}_{2} \mathrm{Y}_{4}$ receptors on astrocytes augment their expression only in ipsilateral substantia nigra
Fig. 3 6-Hydroxydopamine modulates the expression of selected $\mathrm{P} 2$ receptor proteins in striatum and substantia nigra. Staining of rat substantia nigra after 6-hydroxydopamine treatment. Panel A Conventional microscopy images of Nissl staining shows several dopaminergic neurons (arrows) in the contralateral control hemisphere, which are lost (asterisks) in the ipsilateral

lesioned hemisphere. Specific ipsilateral dopaminergic lesion of substantia nigra pars compacta (SNC) was also visualized by confocal THimmunostaining (green) (insets $a, b)$. Panel $B$ Confocal merged yellow images show upregulation of $\mathrm{P} 2 \mathrm{X}_{1}$ receptor protein (red) in parvalbumin-positive GABAergic neurons (green) in the lesioned side of substantia nigra pars reticolata (SNR) of 6-hydroxydopamine-treated rats. Panel C Confocal merged yellow images show a drastic increase in GFAP-positive astrocytes (green) in the lesioned side of 6-hydroxydopamine-treated rats and, correspondingly, an augment of $\mathrm{P}_{2} \mathrm{Y}_{4}$ signal (red) (inset $c$ ). Scale bars are $100 \mu \mathrm{m}$ in $A, B$ and in insets $a, b ; 20 \mu \mathrm{m}$ in $C$; and $10 \mu \mathrm{m}$ in inset $c$. Similar results were obtained in at least three independent experiments
Control side

A

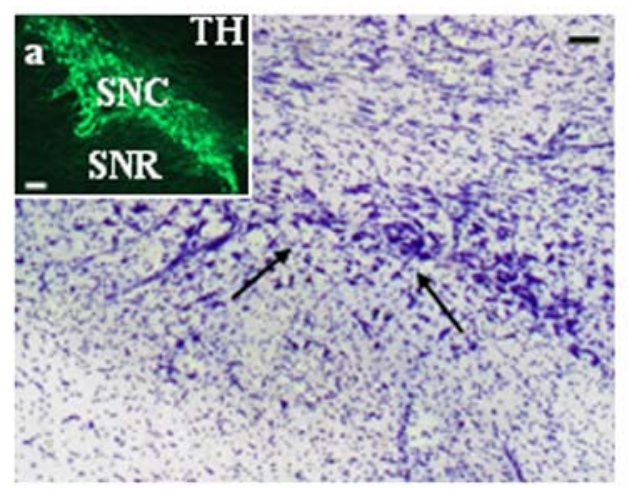

B

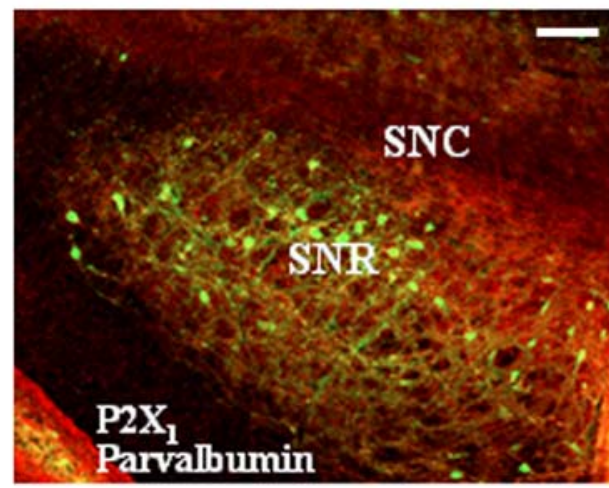

C

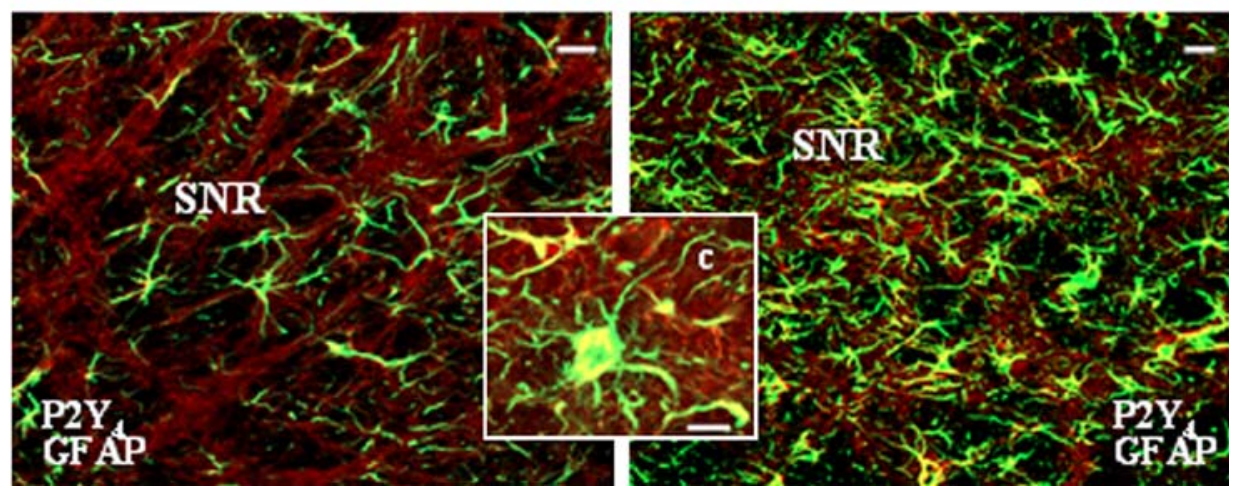

Ipsilateral lesioned side
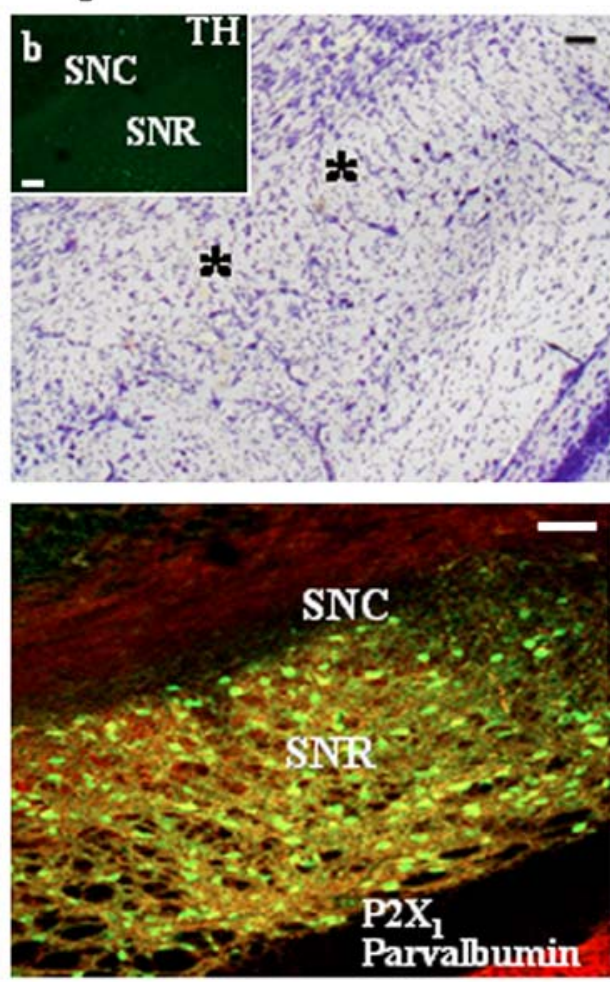
Table 2 Map of P2 receptor modulation after dopamine denervation

\begin{tabular}{|c|c|c|}
\hline & Ipsilateral Striatum & Ipsilateral SN \\
\hline $\mathrm{P} 2 \mathrm{X}_{1}$ & $=$ & $\uparrow \mathrm{GABA}$ \\
\hline $\mathrm{P} 2 \mathrm{X}_{2}$ & $\downarrow$ GABA & $\downarrow \mathrm{TH}$ \\
\hline $\mathrm{P} 2 \mathrm{X}_{3}$ & $\downarrow$ GABA & $\downarrow \mathrm{TH}, \uparrow \mathrm{GABA}$ \\
\hline $\mathrm{P} 2 \mathrm{X}_{4}$ & $\downarrow$ GABA & $\downarrow \mathrm{TH}, \uparrow \mathrm{GABA}$ \\
\hline $\mathrm{P} 2 \mathrm{X}_{5}$ & $=$ & $\downarrow \mathrm{TH}$ \\
\hline $\mathrm{P} \mathrm{X}_{6}$ & $=$ & $\downarrow \mathrm{TH}, \uparrow \mathrm{GABA}$ \\
\hline $\mathrm{P} 2 \mathrm{X}_{7}$ & $=$ & $=$ \\
\hline $\mathrm{P} 2 \mathrm{X}_{1}$ & $=$ & $\downarrow \mathrm{TH}$ \\
\hline $\mathrm{P} 2 \mathrm{X}_{2}$ & $=$ & $=$ \\
\hline $\mathrm{P} 2 \mathrm{X}_{4}$ & $\downarrow \mathrm{GABA}$ & $\uparrow$ GFAP \\
\hline $\mathrm{P} 2 \mathrm{X}_{6}$ & $=$ & $\downarrow \mathrm{TH}$ \\
\hline $\mathrm{P} 2 \mathrm{X}_{11}$ & $=$ & $=$ \\
\hline $\mathrm{P} 2 \mathrm{X}_{12}$ & $=$ & $=$ \\
\hline $\mathrm{P} 2 \mathrm{X}_{13}$ & $=$ & $=$ \\
\hline $\mathrm{P} 2 \mathrm{X}_{14}$ & $=$ & $\downarrow \mathrm{TH}$ \\
\hline
\end{tabular}

Relative increase $(\uparrow)$ or decrease $(\downarrow)$ in P2X and P2Y receptor proteins analyzed by confocal immunofluorascence microscopy in striatum and $\mathrm{SN}$ after treatment in rat in vivo with 6-hydroxydopamine (ipsilateral), and in control (not lesioned) brain hemisphere (contralateral). $\mathrm{TH}=$ presence in dopaminergic neurons, $G A B A=$ presence in GABAergic neurons, GFAP = presence in astrocytes

pars reticulata adjacent to the lesioned pars compacta. In this same area, a phenomenon of astrogliosis is also induced, as detected by more abundant expression of GFAP-positive astrocytes (Fig. 3C).

\section{Discussion}

Because the roles of ATP in the CNS have received less attention until recently, often due to lack of appropriate research tools, our knowledge of the functional qualification of $\mathrm{P} 2$ receptors in the brain is limited, although rapidly improving. As a group of nuclei interconnected with cerebral cortex, thalamus and brainstem, and associated with a variety of functions, such as motor control, cognition, emotions and learning, the BG [32] is an area that deserves thorough analysis. Our work was aimed at mapping in vivo the presence of $\mathrm{P} 2$ receptor subtypes in the BG nuclei of striatum and SN by immunofluorescenceconfocal and Western blotting techniques. The specificity of the highly sensitive molecular probes used for the detection of all known P2X and P2Y receptor proteins has been previously validated $[33,34]$. In addition, we undertook an analysis that excluded possible cross-reactivity for all antisera used.

Our results not only establish that the majority of $\mathrm{P} 2 \mathrm{X}$ $\left(\mathrm{P} 2 \mathrm{X}_{1-7}\right)$ and $\mathrm{P} 2 \mathrm{Y}\left(\mathrm{P} 2 \mathrm{Y}_{1,2,4,6,11-14}\right)$ receptors so far cloned from mammalian tissues are found in striatum and $\mathrm{SN}$, but also prove their distinctive localization on neurons and/or glial cells. In detail we show that, with the exception of only $\mathrm{P}_{2} \mathrm{Y}_{11}$ and $\mathrm{P} 2 \mathrm{Y}_{13}$ receptors (whose immunoreactivity was not identified by any means under our experimental conditions), all other subtypes are specifically localized in striatum and SN (both pars compacta and reticulata), although with different levels of expression, rated as low $\left(\mathrm{P}^{2} \mathrm{X}_{5,6}\right.$ and $\mathrm{P} 2 \mathrm{Y}_{1,6,14}$ in striatum), medium $\left(\mathrm{P} 2 \mathrm{X}_{3}\right.$ in striatum and $\mathrm{SN} ; \mathrm{P}_{2} \mathrm{X}_{6,7}$ and $\mathrm{P}_{2} \mathrm{Y}_{1}$ in $\mathrm{SN}$ ) and high. Moreover, while we show a prevalence of $\mathrm{P} 2$ receptors on neurons $\left(\mathrm{P} 2 \mathrm{X}_{1,4}\right.$ and $\mathrm{P} 2 \mathrm{Y}_{2}$ colocalizing with neurofilament light, medium and heavy chains) with features that are either dopaminergic ( $\mathrm{P} 2 \mathrm{X}_{2-5}$ and $\mathrm{P}_{2} \mathrm{Y}_{1,4,6,14}$ colocalizing with $\mathrm{TH}$, in $\mathrm{SN})$ or GABAergic $\left(\mathrm{P}_{2} \mathrm{X}_{2-4}\right.$ and $\mathrm{P}_{2} \mathrm{Y}_{4}$ colocalizing with parvalbumin and calbindin, in striatum), we also describe their expression on astrocytes ( $\mathrm{P}_{2} \mathrm{Y}_{2,4}$ in striatum and SN, colocalizing with GFAP), microglia ( $\mathrm{P}_{2}$, colocalizing with $\mathrm{OX} 42$ ) [27], and oligodendrocytes (P2 $\mathrm{Y}_{12}$, colocalizing with MBP and RIP) [26]. By confirming previous autoradiographic studies $[35,36]$, our results therefore prove the widespread but diversified P2receptor protein distribution in striatum and $\mathrm{SN}$, and extend to these nuclei the great level of biological complexity and molecular sophistication pertaining to $\mathrm{P} 2$ receptors [3].

Although the configuration of receptor subunits required for assembly into functional cation channels gated by extracellular ATP in different regions of the CNS comprising the BG is not known yet, colocalization of so many different P2X subtypes in striatum and $\mathrm{SN}$ is definitely compatible with heteromultimeric assembly of ionotropic subunits. Since a growing body of biochemical and biophysical evidence now indicates that the propensity to form homo- and especially hetero-multimers is frequent also for $G$ protein-coupled receptors [37] comprising the P2Y subtypes [30, 31], the concurrent expression in striatum and $\mathrm{SN}$ of as many metabotropic receptors could explain once more a complex hetero-oligomeric architecture. Nevertheless, the biological phenomenon of redundancy could also justify the simultaneous presence of multiple P2 receptor subtypes in these nuclei, with the final outcome of increasing the structural and pharmacological heterogeneity of these brain regions. Finally, the composite architecture of $\mathrm{P} 2$ receptors that we depicted in striatum and SN might likely also signify a multipart mechanism of receptor cooperative behavior (Volonté et al., personal communication) that sustains the concomitant level of complexity of this brain area in several tasks, such as planning and modulation of movement pathways, cognitive processes involving executive functions, reward and addiction. These possibilities are, of course, not mutually exclusive.

Striatal neurons, including the most abundant medium spiny neurons, receive convergent synaptic modulation from nigral dopaminergic neurons and from cortical 
glutamatergic projections [38]. The present study showing that lesions of nigral dopaminergic neurons do not significantly affect purinergic receptors present on axons of striatum white matter, but do generate a significant overall decrease in $\mathrm{P} 2 \mathrm{X}$ and $\mathrm{P} 2 \mathrm{Y}$ receptor proteins from striatal spiny neurons and GABAergic interneurons, thus confirms and extends the involvement of $\mathrm{P} 2$ receptors and extracellular ATP to the cortex-basal ganglia circuit [21]. Since dopaminergic denervation affects not only the nigrostriatal dopaminergic pathway but, as a consequence, the corticostriatal glutamatergic pathway with an increase in glutamatergic transmission [39-41] and extracellular glutamate levels in the striatum [42], the reduced P2 receptor protein expression that we demonstrate in striatum gray matter could thus not only be a direct effect of the nigrostriatal inhibition, but also a cause of de-inhibitory mechanisms occurring in the corticostriatal circuit. In this regard, it is common knowledge that extracellular ATP participates in excitatory neurotransmission in the CNS [43], that release of extracellular ATP occurs in CNS under both normal and pathological conditions [44] and, not least, that glutamate release is induced by extracellular ATP in CNS glutamatergic neurons [45].

Neurons of the pars compacta responsible for dopamine production in the brain, which we have shown here to completely lose their array of P2 receptors as a consequence of neurodegeneration induced by 6-OHDA treatment, receive inhibiting signals also from neurons of the pars reticulata that produce GABA [46]. Loss of dopamine neurons in the SNC, one of the main pathological features of Parkinson's disease leading to a marked reduction in dopamine function in the brain, thus also impedes the inhibitory pathway of SNR, with a consequent overactivation of GABAergic neurons. Our findings that specific expression of both ionotropic $\mathrm{P} 2 \mathrm{X}_{1,3,4,6}$ receptors on GABAergic neurons and metabotropic $\mathrm{P}_{2} \mathrm{Y}_{4}$ receptors on astrocytes is remarkably increased in SNR after dopamine denervation thus probably reflects a parallel compensatory overreaction of GABAergic neurons to dopamine shortage. One possible explanation is that purinergic mechanisms might thus play a crucial role in the fine-tuned regulation not only of dopaminergic and glutamatergic cross-talk in striatum, as it occurs in nucleus accumbens [47], but also of GABAergic and dopaminergic interplay in $\mathrm{SN}$, as it occurs in the mesolimbic neuronal circuit [48]. This is consistent with the overall versatile functions accomplished by P2 receptors in the CNS under both normal and pathological conditions [43, 44, 49] and, in particular, with the intermediary role in oligodendrocyte-to-neuron [26], Bergmann glia-to-neuron, and neuron-to-neuron communication [50] proposed for $\mathrm{P} 2$ receptors in various brain regions.

In summary, the importance of our work is twofold. We first provide the complete topographical analysis of all known $\mathrm{P} 2 \mathrm{X}$ and $\mathrm{P} 2 \mathrm{Y}$ receptor subtypes expressed in vivo at their protein levels in rat striatum and $\mathrm{SN}$, which, when considered alongside functional studies, supports a key role for extracellular ATP as a cotransmitter/neuromodulator in these brain areas. Then, we prove that dopamine denervation in the 6-OHDA animal model of Parkinson's disease generates a significant rearrangement of P2 receptor proteins in these nuclei, therefore disclosing the participation of $\mathrm{P} 2$ receptors in the lesioned nigro-striatal circuit. While requiring further investigation, our findings indicate a potential but noteworthy pharmacological and therapeutic novel outcome for Parkinson's disease.

Acknowledgements The research presented was supported by Cofinanziamento MIUR "Purinoceptors and Neuroprotection," and a grant from Ministero della Salute RF05.105V.

\section{References}

1. Burnstock G (2007a) Physiology and pathophysiology of purinergic neurotransmission. Physiol Rev 87:659-797

2. Burnstock G (2007b) Purine and pyrimidine receptors. Cell Mol Life Sci 64:1471-1483

3. Volonté C, Amadio S, D'Ambrosi N, Colpi M, Burnstock G (2006) P2 receptor web: complexity and fine-tuning. Pharmacol Ther 112:264-280

4. Lê KT, Babinski K, Seguela P (1998) Central P2X4 and P2X6 channel subunits coassemble into a novel heteromeric ATP receptor. J Neurosci 18:7152-7159

5. Llewellyn-Smith IJ, Burnstock G (1998) Ultrastructural localization of P2X3 receptors in rat sensory neurons. NeuroReport 9:2245-2250

6. Loesch A, Burnstock G (1998) Electron-immunocytochemical localization of $\mathrm{P} 2 \mathrm{X} 1$ receptors in the rat cerebellum. Cell Tissue Res 294:253-260

7. Xiang Z, Bo X, Burnstock G (1998) Localization of ATP-gated $\mathrm{P} 2 \mathrm{X}$ receptor immunoreactivity in rat sensory and sympathetic ganglia. Neurosci Lett 256:105-108

8. Nörenberg W, Illes P (2000) Neuronal P2X receptors: localisation and functional properties. Naunyn Schmiedebergs Arch Pharmacol 362:324-339

9. Rubio ME, Soto F (2001) Distinct localization of P2X receptors at excitatory postsynaptic specializations. J Neurosci 21:641-653

10. North RA (2002) Molecular physiology of P2X receptors. Physiol Rev 82:1013-1067

11. Burnstock G, Knight GE (2004) Cellular distribution and functions of P2 receptor subtypes in different systems. Int Rev Cytol 240:31-304

12. Moran-Jimenez M, Matute C (2000) Immunohistochemical localization of the $\mathrm{P} 2 \mathrm{Y} 1$ purinergic receptor in neurons and glial cells of the central nervous system. Brain Res 78:50-58

13. Moore D, Chambers J, Waldvogel H, Faull R, Emson P (2000) Regional and cellular distribution of the P2Y1 purinergic receptor in the human brain: striking neuronal localisation. J Comp Neurol 421:374-384

14. Laitinen JT, Uri A, Raidaru G, Miettinen R (2001) [35S]GTPgS autoradiography reveals a wide distribution of Gi/o-linked ADP receptors in the nervous system: close similarities with the platelet P2Y(ADP) receptor. J Neurochem 77:505-518 
15. Burnstock G (2003) Purinergic receptors in the nervous system. In: Schwiebert EM (ed) Current topics in membranes. Purinergic receptors and signalling, vol. 54. Academic, San Diego, pp 307-368

16. Scheibler P, Pesic M, Franke H, Reinhardt R, Wirkner K, Illes P, Norenberg W (2004) P2X2 and P2Y1 immunofluorescence in rat neostriatal medium-spiny projection neurones and cholinergic interneurons is not linked to respective purinergic receptor function. Br J Pharmacol 143:119-131

17. Vulchanova L, Arvidsson U, Riedl M, Wang J, Buell G, Surprenant A, North RA, Elde R (1996) Differential distribution of two ATP-gated channels (P2X receptors) determined by immunocytochemistry. Proc Natl Acad Sci USA 93:8063-8067

18. Kanjhan R, Housley GD, Burton LD, Christie DL, Kippenberger A, Thorne PR, Luo L, Ryan AF (1999) Distribution of the P2X2 receptor subunit of the ATP-gated ion channels in the rat central nervous system. J Comp Neurol 407:11-32

19. Collo G, North RA, Kawashima E, Merlo-Pich E, Neidhart S, Surprenant A, Buell G (1996) Cloning of P2X5 and P2X6 receptors and the distribution and properties of an extended family of ATP-gated ion channels. J Neurosci 16:2495-2507

20. Zhang J, Kornecki E, Jackman J, Ehrlich YH (1988) ATP secretion and extracellular protein phosphorylation by CNS neurons in primary culture. Brain Res Bull 21:459-464

21. Ikeuchi Y, Nishizaki T (1995) ATP-evoked potassium currents in rat striatal neurons are mediated by a $\mathrm{P} 2$ purinergic receptor. Neurosci Lett 190:89-92

22. Zhang YX, Yamashita H, Ohshita T, Sawamoto N, Nakamura S (1995) ATP increases extracellular dopamine level through stimulation of P2Y purinoceptors in the rat striatum. Brain Res 691:205-212

23. Trendelenburg AU, Bultmann R (2000) P2 receptor-mediated inhibition of dopamine release in rat neostriatum. Neuroscience 96:249-252

24. Amadio S, D'Ambrosi N, Cavaliere F, Murra B, Sancesario G, Bernardi G, Burnstock G, Volonté C (2002) P2 receptor modulation and cytotoxic function in cultured CNS neurones. Neuropharmacology 42:489-501

25. Ryu JK, Kim J, Choi SH, Oh YJ, Lee YB, Kim SU, Jin BK (2002) ATP-induced in vivo neurotoxicity in the rat striatum via P2 receptors. NeuroReport 13:1611-1615

26. Amadio S, Tramini G, Martorana A, Viscomi MT, Sancesario G, Bernardi G, Volontè C (2006) Oligodendrocytes express P2Y12 metabotropic receptor in adult rat brain. Neuroscience 141:1171-1180

27. Melani A, Amadio S, Gianfriddo M, Vannucchi MG, Volontè C, Bernardi G, Pedata F, Sancesario G (2006) P2X7 receptor modulation on microglial cells and reduction of brain infarct caused by middle cerebral artery occlusion in rat. J Cereb Blood Flow Metab 26:974-982

28. Paxinos G, Watson C, Pennisi M, Topple A (1985) Bregma, lambda and the interaural midpoint in stereotaxic surgery with rats of different sex, strain and weight. J Neurosci Methods 13:139-143

29. Schwarting RK, Huston JP (1996) The unilateral 6-hydroxydopamine lesion model in behavioral brain research. Analysis of functional deficits, recovery and treatments. Prog Neurobiol 50:275-331

30. D'Ambrosi N, Iafrate M, Vacca F, Amadio S, Tozzi A, Mercuri NB, Volonté C (2006) The P2Y4 receptor forms homo-oligomeric complexes in several CNS and PNS neuronal cells. Purinergic Signal 2:575-582

31. D'Ambrosi N, Iafrate M, Saba E, Rosa P, Volonté C (2007) Comparative analysis of $\mathrm{P} 2 \mathrm{Y}(4)$ and $\mathrm{P} 2 \mathrm{Y}(6)$ receptor architecture in native and transfected neuronal systems. Biochim Biophys Acta 1768:1592-1599
32. Fisone G, Håkansson K, Borgkvist A, Santini E (2007) Signaling in the basal ganglia: postsynaptic and presynaptic mechanisms. Physiol Behav. DOI 10.1016/j.physbeh.2007.05.028

33. Bianco F, Fumagalli M, Pravettoni E, D’Ambrosi N, Volontè C, Matteoli M, Abbracchio MP, Verderio C (2005) Pathophysiological roles of extracellular nucleotides in glial cells: differential expression of purinergic receptors in resting and activated microglia. Brain Res Brain Res Rev 48:144-156

34. Fries JE, Goczalik IM, Wheeler-Schilling TH, Kohler K, Guenther E, Wolf S, Wiedemann P, Bringmann A, Reichenbach A, Francke M, Pannicke T (2005) Identification of P2Y receptor subtypes in human muller glial cells by physiology, single cell RT-PCR, and immunohistochemistry. Invest Ophthalmol Vis Sci 46:3000-3007

35. Bo X, Burnstock G (1994) Distribution of [3H]alpha,betamethylene ATP binding sites in rat brain and spinal cord. NeuroReport 5:1601-1604

36. Balcar VJ, Li Y, Killinger S, Bennett MR (1995) Autoradiography of P2x ATP receptors in the rat brain. Br J Pharmacol 115:302306

37. Javitch JA (2004) The ants go marching two by two: oligomeric structure of G-protein-coupled receptors. Mol Pharmacol 66:1077-1082

38. Calabresi P, Picconi B, Tozzi A, Di Filippo M (2007) Dopaminemediated regulation of corticostriatal synaptic plasticity. Trends Neurosci 30:211-219

39. Calabresi P, Mercuri NB, Sancesario G, Bernardi G (1993) Electrophysiology of dopamine-denervated striatal neurons. Implications for Parkinson's disease. Brain 116:433-452

40. Onn SP, West AR, Grace AA (2000) Dopamine-mediated regulation of striatal neuronal and network interactions. Trends Neurosci 23(10 Suppl):S48-S56

41. Picconi B, Pisani A, Centonze D, Battaglia G, Storto M, Nicoletti F, Bernardi G, Calabresi P (2002) Striatal metabotropic glutamate receptor function following experimental parkinsonism and chronic levodopa treatment. Brain 125(Pt 12):2635-2645

42. Robelet S, Melon C, Guillet B, Salin P, Kerkerian-Le Goff L (2004) Chronic L-DOPA treatment increases extracellular glutamate levels and GLT1 expression in the basal ganglia in a rat model of Parkinson's disease. Eur J Neurosci 20:1255-1266

43. Volonté C, Amadio S, Cavaliere F, D’Ambrosi N, Vacca F, Bernardi G (2003) Extracellular ATP and neurodegeneration. Curr Drug Targets CNS Neurol Disord 2:403-412

44. Franke H, Illes $P$ (2006) Involvement of P2 receptors in the growth and survival of neurons in the CNS. Pharmacol Ther 109:297-324

45. Merlo D, Volonté C (1996) Binding and functions of extracellular ATP in cultured cerebellar granule neurons. Biochem Biophys Res Comm 225:907-914

46. Tepper JM, Lee CR (2007) GABAergic control of substantia nigra dopaminergic neurons. Prog Brain Res 160:189-208

47. Krügel U, Kittner H, Illes P (2001) Mechanisms of adenosine 5'triphosphate-induced dopamine release in the rat nucleus accumbens in vivo. Synapse 39:222-232

48. Krügel U, Kittner H, Franke H, Illes P (2003) Purinergic modulation of neuronal activity in the mesolimbic dopaminergic system in vivo. Synapse 47:134-142

49. Koles L, Furst S, Illes P (2005) P2X and P2Y receptors as possible targets of therapeutic manipulations in CNS illnesses. Drug News Perspect 18:85-101

50. Amadio S, Vacca F, Martorana A, Sancesario G, Volonté C (2007) $\mathrm{P}_{2} \mathrm{Y}_{1}$ receptor switches to neurons from glia in juvenile versus neonatal rat cerebellar cortex. BMC Dev Biol 7(1):77 